Bull. Fac. Agric., Cairo Univ., 67: 327-340(2016).

\title{
EFFECT OF USING DIFFERENT IRRIGATION LEVELS AND SEAWEED EXTRACT CONCENTRATIONS ON THE GROWTH, YIELD AND PODS QUALITY OF GREEN BEAN (Phaseolus vulgaris $\mathbf{L}$.).
}

(Received: 30.10.2016)

\author{
By \\ M.T.G El-Abd, A. H. M. Abd Elwahed and E. A. Ashmawi \\ Department of Horticulture, Faculty of Agriculture, AL-Azhar University, Cairo, Egypt.
}

\begin{abstract}
The present study was carried out in a private farm at Meet Assas, Samanoud, Elgharbia Governorate, Egypt, during the two fall seasons of 2014 and 2015. The experiment was conducted to investigate the effect of three irrigation water levels mainly 60, 80 and $100 \%$ of crop evapotranspiration (ETC) and seaweed extract as a foliar spray at the concentrations of 400, 600 and $800 \mathrm{ppm}$ and their interaction on the growth, yield and pod quality of green bean (Phaseolus vulgaris L.) cultivar Bronco. The obtained results showed that plant height and the number of leaves and pod weight and length as well as leaf relative water content significantly increased with using the irrigation level at $100 \%$ of Etc and the seaweed extract at concentration of $800 \mathrm{ppm}$. The same trend was obtained for pod contents of total protein, $\mathrm{N}, \mathrm{P}$ and $\mathrm{K}$. On the other hand, the highest values of total chlorophyll content in the leaf in addition to total yield as weight and number of pods per plant resulted from the irrigation levels at $80 \%$ and $100 \%$ of Etc and the seaweed extract concentration of $800 \mathrm{ppm}$. While, leaf proline content and pod content of ascorbic acid significantly increased with decreasing irrigation water level to $60 \%$ in the plants sprayed with the concentration of $800 \mathrm{ppm}$ seaweed extract. At the same time, the highest value of water saturation deficit was obtained from applying the irrigation level at $60 \%$ of Etc in the untreated plants with seaweed extract. Also, it seems that the highest values of water use efficiency resulted from using the level of $80 \%$ from Etc. It could be concluded that using the irrigation level at $80 \%$ of Etc and spraying the plants with the seaweed extract at $800 \mathrm{ppm}$ is considered a suitable application to increase the yield of green bean with high water use efficiency.
\end{abstract}

Key words: green bean, irrigation levels, seaweed extract.

\section{INTRODUCTION}

Green bean (Phaseolus vulgaris L.) is one of the most important vegetable crops grown in Egypt for either local consumption or exportation .The cultivated area of this crop in 2013 was estimated at 25.071 feddan, which produced about 263.080 tons with an average yield of 10.49 tons per feddan ( FAO, 2013). Water is a limiting factor with respect to its quantity and quality in crop production. Nowadays, the shortage of irrigation water is the major challenge which faces agricultural production in Egypt. Beans, like many other crops, are sensitive to water stress at all growth stages and it is more sensitive to drought at flowering and pod development stages (Thaloot $e t$ al., 2006). Trials of bean plants showed that vegetative growth and pod yield were significantly influenced by water stress treatments (Singer et al., 2003). Hence, the detrimental effects of drought can be minimized by adequate and balanced supply of exogenous applied antioxidant compounds as well as application of various organic solutes (Ibrahim, 2012 and Mansori et al., 2016). It is well known that seaweed extract is useful for ensuring high agricultural production and it is an important resource for diverse components which have beneficial effects, in terms of enhancement of plant growth and development (Hernández- Herrera et al., 2014), improving tolerance to environment stress and 
increasing antioxidant properties of plants (Zhang et al., 2003). Therefore, the main objective of the current study was to evaluate the effect of foliar spray with some concentrations of seaweed extract on the growth and the changes in the physical and chemical characteristics of green bean under different irrigation water levels.

\section{MATERIALS AND METHODS}

This trial was carried out during the two fall seasons of 2014 and 2015 at a private farm at Meet Assas, Samanoud, Elgharbia Governorate, Egypt. The aim was to study the effect of the various irrigation water levels, seaweed concentrations and their interaction on the growth, yield and pods quality of green bean (Phaseolus vulgaris L.) cultivar Bronco. The seeds were directly sown in the field on September the $3^{\text {rd }}$ in the two seasons. Planting spacing was done at $60 \mathrm{~cm}$. between rows and $20 \mathrm{~cm}$. between plants in the row. Each row was $3 \mathrm{~m}$ long and $60 \mathrm{~cm}$ wide. The area of each plot was $6 \mathrm{~m}^{2}$. After complete germination plants were thinned into one plant per hill. This experiment included 12 treatments, which were the combinations between three irrigation water levels and four treatments of seaweed extract. The treatments were arranged as a factorial in a randomized complete block design with three replicates. Drip irrigation was applied at three irrigation levels including 60, 80 and $100 \%$ of crop evapotranspiration (Etc) which was determined by using Penman Montieth equation (Allen et al., 1998). The total amounts of irrigation water requirement $\left(\mathrm{m}^{3} / \mathrm{fed}\right.$.) were determined in the different treatments during the two growing seasons as shown in Table (1). The water rate was $2 \mathrm{~L} / \mathrm{h}$, discharge at 4 days intervals in the two seasons. One row was left between each irrigation treatment as a guard row to avoid and prevent the overlapping. All experimental units received equal amounts of water until complete germination then irrigation and treatments were started in both seasons. Plants were sprayed with four concentrations of seaweed extract (SWE), namely $400,600,800 \mathrm{ppm}$ and tap water as a control at three times; the first was before flowering, while the second and third were 15 and 30 days after the first spray (Hamed, 2012). The seaweed extract was obtained from Union for Agricultural Development (UAD) Company, Cairo, Egypt. The chemical and biochemical analysies of seaweed extract are shown in Table (2). The obtained results of the physical and chemical analyses of soil experimental site were shown in Table (3). The recommended agricultural practices of growing snap bean were applied whenever needed (Hassan, 1989).

Table (1): Total quantity of water applied with $\left(\mathrm{m}^{3} / \mathrm{fed}\right.$.) for the different irrigation levels during the two growing seasons of 2014 and 2015.

\begin{tabular}{|c|c|c|c|c|c|}
\hline \multicolumn{7}{|c|}{ Total quantity of water applied (m/fed.) } \\
\hline \multicolumn{2}{|c|}{$\mathbf{1 0 0 \%}$} & \multicolumn{2}{c|}{$\mathbf{8 0 \%}$} & \multicolumn{2}{c|}{$\mathbf{6 0 \%}$} \\
\hline 2014 & 2015 & 2014 & 2015 & 2014 & 2015 \\
\hline 1885 & 1980 & 1508 & 1584 & 1131 & 1188 \\
\hline
\end{tabular}

Table (2): Chemical and biochemical analysies of seaweed extract according to $\mathrm{UAD}^{\circledR}$ Company, during 2014 and 2015 seasons.

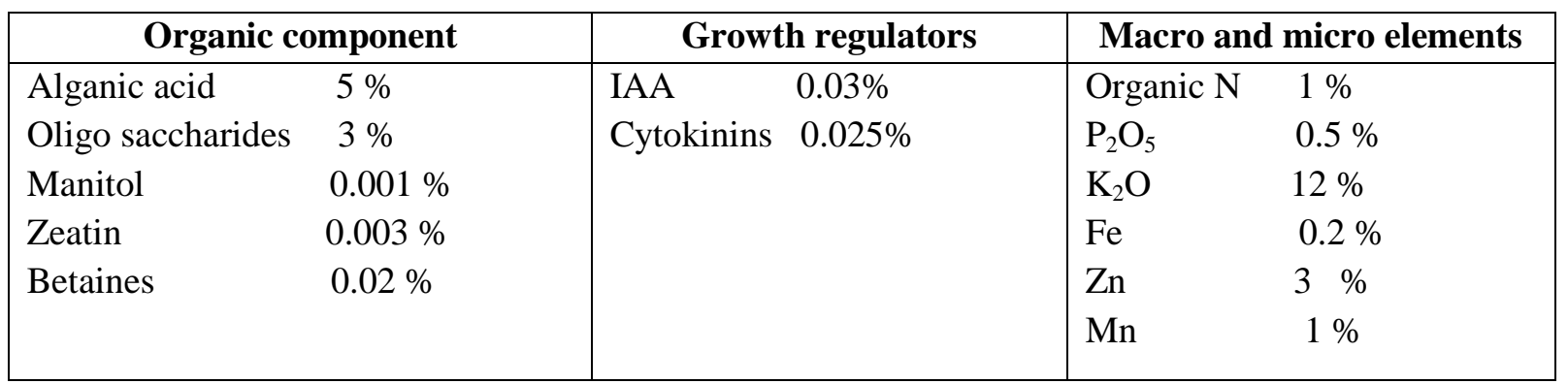


Table (3): The physical and chemical properties of the soil under study.

\begin{tabular}{|c|c|c|c|c|c|c|c|c|c|}
\hline \multicolumn{10}{|c|}{ Physical properties } \\
\hline Clay & \multicolumn{2}{|c|}{ Silt } & \multicolumn{2}{|c|}{ Sand } & Texure & \multicolumn{2}{|c|}{ FC (\%) } & \multicolumn{2}{|c|}{ WP(\%) } \\
\hline 52.44 & \multicolumn{2}{|c|}{23.09} & \multicolumn{2}{|c|}{24.64} & Clay & \multicolumn{2}{|c|}{37.13} & \multicolumn{2}{|c|}{21.9} \\
\hline \multicolumn{10}{|c|}{ Chemical properties } \\
\hline \multirow{2}{*}{$\begin{array}{c}\text { E.C } \\
\text { Mmohs } / \mathbf{c m}^{3}\end{array}$} & \multirow[t]{2}{*}{ pH } & \multicolumn{4}{|c|}{ Cation meq/l } & \multicolumn{4}{|c|}{ Anion meq/l } \\
\hline & & $\mathbf{C a}^{++}$ & $\mathbf{M g}^{++}$ & $\mathrm{Na}^{+}$ & $\mathbf{K}^{+}$ & $\mathrm{Co}_{3}{ }^{--}$ & $\mathrm{HCO}_{3}^{-}$ & $\mathrm{Cl}^{-}$ & $\mathrm{So}_{4}{ }^{--}$ \\
\hline 0.62 & 8.10 & 2.58 & 0.65 & 2.04 & 0.93 & 0 & 1.77 & 2.17 & 2.26 \\
\hline
\end{tabular}

Data recorded:

A. Plant characteristics: Ten plants of green bean from each treatment were randomly taken at 65 days after sowing to measure plant height and the number of leaves as physical characteristics. In addition, chemical constituents in the leaf such as total chlorophyll were determined according to Lichtenthaler (1987) and the total proline content was determined according to Bates et al. (1973).

B. Pod characteristics: pods were harvested after reaching the marketable stage and samples were taken from each treatment to determine the physical characteristics including pod fresh weight and length. Also, chemical constituents in pods mainly total chlorophyll was determined according to Lichtenthaler (1987) and ascorbic acid, total protein, nitrogen, phosphorus and potassium contents were determined by the method published in A.O.A.C (2005).

C.Yield: The pods were harvested from the beginning of the harvesting stage till the end of the growing season where the total yield as weight and the number of pods per plant were recorded.

D. Water relations including water saturation deficit were calculated according to Catasky (1963), relative water content was calculated according to Korkmaz et al. (2010) and water use efficiency was calculated according to Srinivas et al. (1989).

Data were subjected to statistical analysis using the analysis of variance methods and the means of treatments were compared by using the Least Significant Different (L.S.D) at 5\% level of probability according to Snedecor and Cochran (1980).

\section{RESULTS \\ 3.1. Plant characteristics 3.1.1. Physical characteristics}

The effect of the different irrigation water levels, seaweed concentrations and their interaction on the plant physical characteristics of green bean (Table 4) showed that there was significant increase in the values of plant height and the number of leaves with the rise of irrigation water levels up to $100 \%$ of Etc compared with the level of $60 \%$. With respect to the effect of seaweed concentrations, it was found that plant height and the number of leaves significantly increased by using seaweed concentration of 800 ppm as compared with the untreated plants. The interaction among treatments reflected that the highest significant values of plant height and the number of leaves were observed from using the irrigation level at $100 \%$ of Etc and the seaweed application of $800 \mathrm{ppm}$, whereas the lowest one exerted from the level of $60 \%$ of Etc and the untreated plants with the seaweed.

The effect of the different irrigation water levels, seaweed concentrations and their interaction on the plant physical characteristics of green bean (Table 4) showed that there was a significant increase in the values of plant height and the number of leaves with the rise of irrigation water levels up to $100 \%$ of Etc compared with the level of $60 \%$. With respect to the effect of seaweed concentrations, it was found that plant height and the number of leaves significantly increased by using seaweed concentration of 800 ppm as compared with the untreated plants. The interaction among treatments reflected that the highest significant values of plant height and number of leaves were observed from using the irrigation level at $100 \%$ of Etc and the seaweed application of $800 \mathrm{ppm}$, whereas the lowest one exerted from the level of $60 \%$ of Etc and the untreated plants with the seaweed.

\subsubsection{Chemical constituents}

The results of the leaf total chlorophyll content obtained from the irrigation water at the 
Table (4): Effect of the different irrigation water levels, seaweed concentrations and their interaction on the plant physical characteristics of green bean during the two seasons of 2014 and 2015.

\begin{tabular}{|c|c|c|c|c|c|}
\hline \multirow{2}{*}{$\begin{array}{l}\text { Irrigation } \\
\text { levels }(\%)\end{array}$} & \multirow{2}{*}{$\begin{array}{c}\text { Seaweed extract } \\
\text { concentrations (ppm) }\end{array}$} & \multicolumn{2}{|c|}{ Plant height (cm) } & \multicolumn{2}{|c|}{ Number of leaves } \\
\hline & & $\begin{array}{c}2014 \\
\text { season }\end{array}$ & $\begin{array}{c}2015 \\
\text { season }\end{array}$ & $\begin{array}{c}2014 \\
\text { season }\end{array}$ & $\begin{array}{c}2015 \\
\text { season }\end{array}$ \\
\hline \multirow[t]{4}{*}{60} & Control & 40.34 & 43.65 & 16.00 & 16.70 \\
\hline & 400 & 42.00 & 46.66 & 17.59 & 18.00 \\
\hline & 600 & 45.70 & 49.31 & 19.33 & 20.00 \\
\hline & 800 & 49.00 & 52.40 & 21.00 & 21.30 \\
\hline \multicolumn{2}{|r|}{ Mean } & 44.26 & 48.00 & 18.50 & 19.00 \\
\hline \multirow[t]{4}{*}{80} & Control & 51.40 & 53.66 & 24.00 & 23.67 \\
\hline & 400 & 53.32 & 56.34 & 26.66 & 25.32 \\
\hline & 600 & 55.00 & 58.33 & 27.00 & 26.66 \\
\hline & 800 & $\mathbf{5 7 . 6 5}$ & 61.00 & 30.00 & 28.00 \\
\hline \multicolumn{2}{|r|}{ Mean } & 54.34 & 57.34 & 26.92 & 25.91 \\
\hline \multirow[t]{4}{*}{100} & Control & 58.29 & 62.33 & 32.00 & 30.66 \\
\hline & 400 & 60.00 & 63.00 & 34.00 & 33.00 \\
\hline & 600 & 62.00 & 65.00 & 37.00 & 36.00 \\
\hline & 800 & 66.66 & 69.01 & 38.65 & 37.66 \\
\hline \multicolumn{2}{|r|}{ Mean } & 61.74 & 64.83 & 35.42 & 34.33 \\
\hline \multirow{4}{*}{$\begin{array}{c}\text { Mean SWE } \\
\text { concentrations }\end{array}$} & Control & 50.01 & 53.22 & 24.00 & 23.67 \\
\hline & 400 & 51.80 & 55.30 & 26.08 & 25.45 \\
\hline & 600 & 54.22 & 57.55 & 27.80 & 27.60 \\
\hline & 800 & 57.77 & 60.80 & 29.88 & 29.00 \\
\hline \multirow[t]{3}{*}{ L.S.D at $5 \%$} & Irrigation levels & 2.59 & 3.00 & 1.08 & 1.01 \\
\hline & SWE concentrations & 3.25 & 3.19 & 1.40 & 1.32 \\
\hline & Irrigation X SWE & 4.45 & 3.85 & 1.57 & 1.41 \\
\hline
\end{tabular}

different levels, the foliar spray with the different concentrations of seaweed extract and their interaction (Table 5) exhibited that the total chlorophyll content in the leaf increased with the increase of irrigation water levels from $60 \%$ and to $100 \%$ of Etc but the difference resulted from using $80 \%$ and $100 \%$ did not reach significance. On the other hand, the total chlorophyll content in the leaf significantly increased with the increase in the tested applications of seaweed extract from 400 ppm till $800 \mathrm{ppm}$. The interaction effect between irrigation water levels and seaweed concentrations showed that the highest total chlorophyll content resulted from the plants irrigated with the levels at $80 \%$ and $100 \%$ of Etc and sprayed with 800 ppm seaweed, while the least significant one resulted from using the irrigation level at $60 \%$ of Etc in the control treatment of seaweed extract.
Concerning the effect of the different irrigation levels, concentrations of seaweed extract and their interaction on the leaf content of proline (Table 5) indicated that proline content significantly increased with using the irrigation level at $60 \%$ of Etc when comparing with the levels at $80 \%$ and $100 \%$. At the same time, the data indicated that the increase of the applied concentrations of seaweed extract as a foliar application helps to increase the accumulation of proline. The interaction between irrigation water levels and seaweed concentrations reflected that the highest significant value of proline content happened in the irrigation level at $60 \%$ of Etc and the treated plants with the seaweed extract of $800 \mathrm{ppm}$, while the lowest value appeared in the plants subjected under the irrigation level at $100 \%$ of Etc and untreated with seaweed extract. 
Table (5): Effect of the different irrigation water levels, seaweed concentrations and their interaction on the plant chemical constituents of green bean during the two seasons of 2014 and 2015.

\begin{tabular}{|c|c|c|c|c|c|}
\hline \multirow{2}{*}{$\begin{array}{c}\text { Irrigation levels } \\
(\%)\end{array}$} & \multirow{2}{*}{$\begin{array}{c}\text { Seaweed extract } \\
\text { concentration }(\mathrm{ppm})\end{array}$} & \multicolumn{2}{|c|}{ Total chlorophyll (mg/l. f.w.) } & \multicolumn{2}{|c|}{ Proline (mg/g. f.w.) } \\
\hline & & 2014 season & 2015 season & 2014 season & 2015 season \\
\hline \multirow[t]{4}{*}{60} & Control & 82.96 & $\mathbf{8 9 . 8 8}$ & 0.59 & 0.80 \\
\hline & 400 & 85.11 & 92.93 & 0.60 & $\mathbf{0 . 8 2}$ \\
\hline & 600 & 90.19 & 98.61 & 0.61 & 0.83 \\
\hline & 800 & 95.89 & 100.82 & 0.67 & 0.89 \\
\hline \multicolumn{2}{|c|}{ Mean } & 88.54 & 95.56 & 0.62 & 0.84 \\
\hline \multirow[t]{4}{*}{80} & Control & 84.43 & 91.94 & 0.51 & 0.65 \\
\hline & 400 & 90.83 & 94.76 & $\mathbf{0 . 5 3}$ & 0.68 \\
\hline & 600 & 95.87 & $\mathbf{1 0 1 . 7 4}$ & 0.54 & 0.70 \\
\hline & 800 & 102.65 & 106.75 & 0.56 & 0.74 \\
\hline \multicolumn{2}{|c|}{ Mean } & 93.44 & 98.79 & $\mathbf{0 . 5 3}$ & 0.69 \\
\hline \multirow[t]{4}{*}{100} & Control & 90.04 & 92.42 & 0.32 & 0.49 \\
\hline & 400 & 93.37 & 96.48 & 0.34 & 0.50 \\
\hline & 600 & 99.10 & $\mathbf{1 0 2 . 7 5}$ & 0.35 & 0.53 \\
\hline & 800 & 103.45 & 106.91 & 0.37 & 0.56 \\
\hline \multicolumn{2}{|c|}{ Mean } & 96.49 & 99.64 & 0.35 & 0.52 \\
\hline \multirow{4}{*}{$\begin{array}{c}\text { Mean SWE } \\
\text { concentrations }\end{array}$} & Control & 86.94 & 91.41 & 0.47 & 0.64 \\
\hline & 400 & 89.77 & 94.72 & 0.49 & 0.69 \\
\hline & 600 & 95.05 & 101.03 & 0.51 & 0.73 \\
\hline & 800 & 100.66 & 104.82 & 0.53 & 0.67 \\
\hline \multirow[t]{3}{*}{ L.S.D at $5 \%$} & Irrigation levels & 3.11 & 1.08 & 0.02 & 0.01 \\
\hline & SWE concentrations & 3.59 & 2.05 & 0.02 & 0.02 \\
\hline & Irrigation X SWE & 4.22 & 3.56 & 0.04 & 0.03 \\
\hline
\end{tabular}

\subsection{Pod characteristics}

\subsubsection{Physical characteristics}

The obtained data about the effect of the various irrigation levels, seaweed concentrations and their interaction on the studied pod physical characteristic (Table 6) clear that increasing the irrigation levels up to $100 \%$ of Etc gave significant increases in pod weight and length. Concerning the foliar application of seaweed extract, the data showed that the pod physical characteristics significantly increased by increasing seaweed concentrations up to $800 \mathrm{ppm}$. In other words, the highest values in the pod physical characteristic detected from using the $100 \%$ irrigation level of Etc and the seaweed concentration of $800 \mathrm{ppm}$, meanwhile the lowest one was exerted from irrigation with the level $60 \%$ of Etc and the control treatment of seaweed extract.

\subsubsection{Chemical constituents}

The data concerning the effect of the different irrigation levels, concentrations of seaweed extract and their interaction on pod total chlorophyll content (Table 7) indicated that pod total chlorophyll content was significantly increased as affected by the level irrigation at $100 \%$ of Etc compared with the other levels. On the other hand, total chlorophyll content in the pods significantly increased with spraying of the plants with the seaweed concentration of $800 \mathrm{ppm}$. The interaction between irrigation water levels and seaweed concentrations showed that the highest total chlorophyll content exerted from using the irrigation level at $100 \%$ of Etc and the concentration of $800 \mathrm{ppm}$ seaweed extract while the lowest significant one was obtained from using the irrigation level at $60 \%$ of Etc in the control treatment of seaweed extract.

Regarding the content of ascorbic acid in the pods (Table 7), the results reflected a significant increase in the content of ascorbic acid came from using the irrigation level at $60 \%$ of Etc after which there was decreased with every increase in the irrigation levels up to $100 \%$. Evidences from seaweed extract concentrations indicated that this content significantly increased with the increase in the applied concentrations of seaweed extract up 
Table (6): Effect of the different irrigation water levels, seaweed concentrations and their interaction on the pod physical characteristics of green bean during the two seasons of 2014 and 2015.

\begin{tabular}{|c|c|c|c|c|c|}
\hline \multirow{2}{*}{$\begin{array}{c}\text { Irrigation levels } \\
(\%)\end{array}$} & \multirow{2}{*}{$\begin{array}{c}\text { Seaweed extract } \\
\text { concentrations (ppm) }\end{array}$} & \multicolumn{2}{|c|}{ Pod weight (g) } & \multicolumn{2}{|c|}{ Pod length (cm) } \\
\hline & & $\begin{array}{c}2014 \\
\text { season }\end{array}$ & $\begin{array}{c}2015 \\
\text { season }\end{array}$ & $\begin{array}{c}2014 \\
\text { season }\end{array}$ & $\begin{array}{c}2015 \\
\text { season }\end{array}$ \\
\hline \multirow[t]{4}{*}{60} & Control & 4.08 & 3.98 & 10.16 & 9.97 \\
\hline & 400 & 4.20 & 4.18 & 10.80 & 10.50 \\
\hline & 600 & 4.65 & 4.45 & 11.43 & 10.80 \\
\hline & 800 & 4.82 & 5.00 & 11.80 & 11.20 \\
\hline \multicolumn{2}{|c|}{ Mean } & 4.44 & 4.38 & 11.05 & 10.62 \\
\hline \multirow[t]{4}{*}{80} & Control & 4.81 & 4.90 & 11.70 & 11.53 \\
\hline & 400 & 4.95 & 5.15 & 11.93 & 11.83 \\
\hline & 600 & 5.37 & 5.50 & 12.16 & 12.20 \\
\hline & 800 & 5.65 & 5.60 & 12.41 & 12.60 \\
\hline \multicolumn{2}{|c|}{ Mean } & 5.20 & 5.30 & 12.05 & 12.04 \\
\hline \multirow[t]{4}{*}{100} & Control & 4.95 & 5.12 & 12.10 & 12.73 \\
\hline & 400 & 5.29 & 5.33 & 12.20 & 13.00 \\
\hline & 600 & 5.52 & 5.48 & 12.75 & 13.36 \\
\hline & 800 & 5.75 & 5.65 & 13.01 & 13.93 \\
\hline \multicolumn{2}{|c|}{ Mean } & 5.37 & 5.39 & 12.51 & 13.25 \\
\hline \multirow{4}{*}{$\begin{array}{c}\text { Mean SWE } \\
\text { concentrations }\end{array}$} & Control & 4.61 & 4.66 & 11.32 & 11.41 \\
\hline & 400 & 4.81 & 4.89 & 11.70 & 11.78 \\
\hline & 600 & 5.19 & 5.14 & 11.93 & 12.12 \\
\hline & $\mathbf{8 0 0}$ & 5.40 & 5.42 & 12.41 & 12.58 \\
\hline \multirow[t]{3}{*}{ L.S.D at 5\% } & Irrigation levels & 0.03 & 0.03 & 0.12 & 0.17 \\
\hline & SWE concentrations & 0.06 & 0.05 & 0.15 & 0.20 \\
\hline & Irrigation X SWE & 0.08 & 0.10 & 0.20 & 0.35 \\
\hline
\end{tabular}

to $800 \mathrm{ppm}$. Hence, the best results in the content of ascorbic acid in pod was achieved from using the irrigation level at $60 \%$ of Etc in the plants sprayed with the concentration of $800 \mathrm{ppm}$ seaweed extract and the opposite was true from using the irrigation level at $100 \%$ of Etc and unsprayed plants with seaweed extract.

With respect to the effect of the different irrigation levels, concentrations of seaweed extract and their interaction on the protein and $\mathrm{N}, \mathrm{P}$ and $\mathrm{K}$ contents in the pod (Tables 7 and 8) indicated that there was a significant increase in the pod protein and $\mathrm{N}, \mathrm{P}$ and $\mathrm{K}$ contents with the increase of the irrigation levels up to $100 \%$ of Etc. The data of the foliar application of seaweed extract exhibited that the protein, $\mathrm{N}, \mathrm{P}$ and $\mathrm{K}$ contents increased with the increase in the applications of seaweed extract from $400 \mathrm{ppm}$ till $800 \mathrm{ppm}$. Also the obtained results cleared that the highest contents of protein, $\mathrm{N}, \mathrm{P}$ and $\mathrm{K}$ resulted from plants irrigated with the $100 \%$ of Etc and sprayed with $800 \mathrm{ppm}$ seaweed, while the lowest one resulted from using the irrigation level at $60 \%$ of Etc in the control treatment of seaweed extract.

\subsection{Yield}

The results of the irrigation water with the different levels, foliar spray with the different concentrations of seaweed extract and their interaction on the total yield of pods per plant (Table 9) clear that the total yield as weight and number increased by the increase of irrigation levels up to $100 \%$ of Etc in spite of the nonsignificant differences occurred between the two levels of $80 \%$ and $100 \%$ of Etc. On the other side, the total yield (as weight and number) significantly increased with the increase in the tested applications of seaweed extract from $400 \mathrm{ppm}$ till $800 \mathrm{ppm}$. In other words, the highest total yield (as weight and number) resulted from the plants exposed to the levels of $80 \%$ and $100 \%$ of Etc and sprayed with $800 \mathrm{ppm}$ seaweed, while the lowest one resulted from the irrigation level at 60 of Etc 
Table (7): Effect of the different irrigation water levels, seaweed concentrations and their interaction on the pod contents of total chlorophyll, ascorbic acid and protein during the two seasons of 2014 and 2015.

\begin{tabular}{|c|c|c|c|c|c|c|c|}
\hline \multirow[t]{2}{*}{$\begin{array}{l}\text { Irrigation } \\
\text { levels } \\
(\%)\end{array}$} & \multirow[t]{2}{*}{$\begin{array}{l}\text { Seaweed extract } \\
\text { concentrations } \\
(\text { ppm })\end{array}$} & \multicolumn{2}{|c|}{$\begin{array}{l}\text { Total chlorophyll } \\
\text { (mg/l f.w) }\end{array}$} & \multicolumn{2}{|c|}{$\begin{array}{l}\text { Ascorbic acid } \\
\text { (mg/100 g f.w) }\end{array}$} & \multicolumn{2}{|c|}{$\begin{array}{c}\text { Total Protein } \\
\text { (mg/g d.w.) }\end{array}$} \\
\hline & & $\begin{array}{c}2014 \\
\text { season }\end{array}$ & $\begin{array}{c}2015 \\
\text { season }\end{array}$ & $\begin{array}{c}2014 \\
\text { season }\end{array}$ & $\begin{array}{c}2015 \\
\text { season }\end{array}$ & $\begin{array}{c}2014 \\
\text { season }\end{array}$ & $\begin{array}{c}2015 \\
\text { season }\end{array}$ \\
\hline \multirow[t]{4}{*}{60} & Control & 60.46 & 62.43 & 25.50 & 26.88 & 10.2 & 11.9 \\
\hline & 400 & 64.13 & 65.50 & 27.30 & 27.94 & 11.6 & 14.0 \\
\hline & 600 & 66.62 & 69.55 & 28.19 & 30.12 & 13.1 & 15.9 \\
\hline & 800 & 68.58 & 71.05 & 30.00 & 32.82 & 14.4 & 16.8 \\
\hline \multicolumn{2}{|c|}{ Mean } & 64.95 & 67.14 & 27.75 & 29.44 & 12.3 & 14.5 \\
\hline \multirow[t]{4}{*}{80} & Control & 55.21 & 57.97 & 23.28 & 25.19 & 11.9 & 13.3 \\
\hline & 400 & 57.17 & 60.06 & 25.50 & 26.71 & 14.0 & 16.0 \\
\hline & 600 & 59.70 & 63.35 & 27.10 & 28.03 & 15.6 & 17.9 \\
\hline & 800 & 62.56 & 65.00 & 28.50 & 30.12 & 17.0 & 19.7 \\
\hline \multicolumn{2}{|c|}{ Mean } & 58.65 & 61.59 & 26.09 & 27.51 & 14.6 & 16.7 \\
\hline \multirow[t]{4}{*}{100} & Control & 57.88 & 60.00 & 20.00 & 22.24 & 13.5 & 15.6 \\
\hline & 400 & 61.72 & 63.51 & 23.12 & 24.46 & 15.8 & 17.7 \\
\hline & 600 & 64.62 & 65.15 & 25.36 & 26.48 & 17.2 & 19.9 \\
\hline & 800 & 67.14 & 68.48 & 26.71 & 28.31 & 18.9 & 21.7 \\
\hline \multicolumn{2}{|c|}{ Mean } & 62.84 & 58.65 & 23.80 & 25.37 & 16.4 & 18.3 \\
\hline \multirow{4}{*}{$\begin{array}{c}\text { Mean SWE } \\
\text { concentrations }\end{array}$} & Control & $\mathbf{5 7 . 8 5}$ & 60.14 & 22.92 & 24.77 & 11.8 & 13.6 \\
\hline & 400 & 61.01 & 63.02 & 25.31 & 26.37 & 13.8 & 15.9 \\
\hline & 600 & 63.63 & 66.02 & 26.88 & 28.21 & 15.3 & 17.8 \\
\hline & 800 & 66.09 & 68.18 & 28.40 & 30.42 & 16.8 & 19.4 \\
\hline \multirow[t]{3}{*}{ L.S.D at $5 \%$} & Irrigation levels & 1.36 & 0.85 & 0.49 & 0.30 & 0.22 & 0.29 \\
\hline & $\begin{array}{c}\text { SWE } \\
\text { concentrations }\end{array}$ & 1.57 & 0.99 & 0.56 & 0.34 & 0.39 & 0.40 \\
\hline & $\begin{array}{c}\text { Irrigation X } \\
\text { SWE }\end{array}$ & 2.02 & 1.71 & 0.98 & 0.60 & 0.52 & 0.61 \\
\hline
\end{tabular}

in the control treatment of seaweed extract.

\subsection{Water relations}

The changes in water saturation deficit due to the irrigation with the different levels, foliar spray with the different concentrations of seaweed extract and their interaction (Table 10) showed that water saturation deficit significantly decreased with every increase in the irrigation water levels. In the other view, the plants treated with seaweed extract concentrations up to $800 \mathrm{ppm}$ had significant decrease in water saturation deficit as compared with the control treatment. The effect of the interaction between the various irrigation water levels and seaweed concentrations confirm that the highest significant value of water saturation deficit was obtained from applying the $60 \%$ level of Etc in the untreated plant with seaweed extract, while the least one came from irrigation with the level at $100 \%$ of Etc and foliar spray with seaweed extract at $800 \mathrm{ppm}$.

The relative water content in the leaf was affected by the different irrigation levels, concentrations of seaweed extract and their interaction (Table 10). Therefore, the results indicated that the relative water content significantly increased as the levels of irrigation water increased till $100 \%$ of Etc. Neglecting the effect of irrigation water levels, the relative water content significantly increased with the application of seaweed extract at $800 \mathrm{ppm}$ when compared with the control treatment. The relation between the different irrigation water levels and seaweed concentrations reflected that the plants irrigated with the irrigation level at $100 \%$ of Etc and sprayed with the concentration of $800 \mathrm{ppm}$ seaweed extract led to the highest value in the 
Table (8): Effect of the different irrigation water levels, seaweed concenrations and their interaction on the pod contents of total nitrogen, phosphorus and potassium during the two seasons of 2014 and 2015.

\begin{tabular}{|c|c|c|c|c|c|c|c|}
\hline \multirow[t]{2}{*}{$\begin{array}{l}\text { Irrigation } \\
\text { levels (\%) }\end{array}$} & \multirow{2}{*}{$\begin{array}{l}\text { Seaweed extract } \\
\text { concentrations } \\
(\mathbf{p p m})\end{array}$} & \multicolumn{2}{|c|}{$\begin{array}{l}\text { Total nitrogen } \\
\text { (g/100g .d.w) }\end{array}$} & \multicolumn{2}{|c|}{$\begin{array}{l}\text { Phosphorus } \\
\text { (g/100g .d.w) }\end{array}$} & \multicolumn{2}{|c|}{$\begin{array}{l}\text { Potassium } \\
\text { (g/100g .d.w) }\end{array}$} \\
\hline & & $\begin{array}{c}2014 \\
\text { season }\end{array}$ & $\begin{array}{c}2015 \\
\text { season }\end{array}$ & $\begin{array}{c}2014 \\
\text { season }\end{array}$ & $\begin{array}{c}2015 \\
\text { season }\end{array}$ & $\begin{array}{c}2014 \\
\text { season }\end{array}$ & $\begin{array}{c}2015 \\
\text { season }\end{array}$ \\
\hline \multirow[t]{4}{*}{60} & Control & 0.16 & 0.19 & 0.21 & 0.23 & 0.25 & 0.27 \\
\hline & 400 & 0.18 & 0.22 & 0.25 & 0.27 & 0.29 & 0.31 \\
\hline & 600 & 0.21 & 0.25 & 0.28 & 0.29 & 0.37 & 0.36 \\
\hline & 800 & 0.23 & 0.27 & 0.32 & 0.32 & 0.38 & 0.41 \\
\hline \multicolumn{2}{|c|}{ Mean } & 0.19 & 0.23 & 0.27 & 0.28 & 0.32 & 0.34 \\
\hline \multirow[t]{4}{*}{80} & Control & 0.19 & 0.21 & 0.24 & 0.25 & 0.27 & 0.33 \\
\hline & 400 & 0.22 & 0.26 & 0.28 & 0.29 & 0.32 & 0.38 \\
\hline & 600 & 0.25 & 0.28 & 0.30 & 0.34 & 0.37 & 0.43 \\
\hline & 800 & 0.26 & 0.31 & 0.34 & 0.37 & 0.42 & 0.46 \\
\hline \multicolumn{2}{|c|}{ Mean } & 0.23 & 0.27 & 0.29 & 0.31 & 0.35 & 0.40 \\
\hline \multirow[t]{4}{*}{100} & Control & 0.21 & 0.25 & 0.26 & 0.29 & 0.32 & 0.36 \\
\hline & 400 & 0.25 & 0.28 & 0.30 & 0.35 & 0.37 & 0.42 \\
\hline & 600 & 0.27 & 0.32 & 0.34 & 0.38 & 0.42 & 0.46 \\
\hline & 800 & 0.30 & 0.34 & 0.36 & 0.42 & 0.46 & 0.50 \\
\hline \multicolumn{2}{|c|}{ Mean } & 0.26 & 0.30 & 0.32 & 0.36 & 0.40 & 0.43 \\
\hline \multirow{4}{*}{$\begin{array}{c}\text { Mean SWE } \\
\text { concentrations }\end{array}$} & Control & 0.19 & 0.22 & 0.23 & 0.26 & 0.28 & 0.32 \\
\hline & 400 & 0.22 & 0.25 & 0.28 & 0.30 & 0.33 & 0.37 \\
\hline & 600 & 0.25 & 0.28 & 0.31 & 0.33 & 0.39 & 0.42 \\
\hline & 800 & 0.27 & 0.31 & 0.34 & 0.38 & 0.42 & 0.46 \\
\hline \multirow[t]{3}{*}{ L.S.D at $5 \%$} & Irrigation levels & 0.01 & 0.01 & 0.01 & $\mathbf{0 . 0 1}$ & 0.01 & 0.01 \\
\hline & $\begin{array}{c}\text { SWE } \\
\text { concentrations } \\
\end{array}$ & 0.01 & 0.01 & 0.01 & 0.01 & 0.02 & 0.01 \\
\hline & $\begin{array}{l}\text { Irrigation } X \\
\text { SWE }\end{array}$ & 0.01 & 0.01 & 0.01 & 0.01 & $\mathbf{0 . 0 3}$ & 0.01 \\
\hline
\end{tabular}

relative water content and the opposite was true from using $60 \%$ level of Etc and unsprayed plants with seaweed extract.

The results established from the effect of the different irrigation levels, concentrations of seaweed extract and their interaction on water use efficiency (Table.10) showed that there was a significant increase in water use efficiency with the increase in the irrigation levels up to $80 \%$ of Etc after which a significant decrease happened in the level of $100 \%$. The view of the concentration of seaweed extract indicated that water use efficiency increased with the increase in the applications of seaweed extract $800 \mathrm{ppm}$. Another picture caught from the obtained results cleared that the highest values of water use efficiency resulted from using the $80 \%$ level of Etc and the concentration of $800 \mathrm{ppm}$ seaweed extract, while the lowest significant one resulted from using the irrigation $60 \%$ level of Etc in the control treatment of seaweed extract. 
Table (9): Effect of the different irrigation water levels, seaweed concentrations and their interaction on the total yield as weight and the number per plant during the two seasons of 2014 and 2015.

\begin{tabular}{|c|c|c|c|c|c|}
\hline \multirow{2}{*}{$\begin{array}{c}\text { Irrigation } \\
\text { levels } \\
(\%)\end{array}$} & \multirow{2}{*}{$\begin{array}{l}\text { Seaweed extract } \\
\text { concentrations } \\
(\mathbf{p p m})\end{array}$} & \multicolumn{2}{|c|}{$\begin{array}{c}\text { Total yield in weight } \\
\text { /plant (g) }\end{array}$} & \multicolumn{2}{|c|}{$\begin{array}{c}\text { Total yield in number } \\
\text { /plant }\end{array}$} \\
\hline & & $\begin{array}{c}\text { 2013-2014 } \\
\text { season }\end{array}$ & $\begin{array}{c}\text { 2014-2015 } \\
\text { season }\end{array}$ & $\begin{array}{c}\text { 2013-2014 } \\
\text { season }\end{array}$ & $\begin{array}{c}\text { 2014-2015 } \\
\text { season }\end{array}$ \\
\hline \multirow[t]{4}{*}{60} & Control & 63.36 & 59.70 & 15.53 & 15.00 \\
\hline & 400 & 69.30 & 69.88 & 16.50 & 16.72 \\
\hline & 600 & 82.67 & 81.88 & 17.70 & 18.40 \\
\hline & 800 & 95.43 & 100.00 & 19.80 & 20.00 \\
\hline \multicolumn{2}{|c|}{ Mean } & 77.69 & 77.86 & 17.38 & 17.53 \\
\hline \multirow[t]{4}{*}{80} & Control & 96.20 & 107.8 & 20.00 & 22.00 \\
\hline & 400 & 113.85 & 123.6 & 23.00 & 24.00 \\
\hline & 600 & 128.88 & 139.09 & 24.00 & 25.29 \\
\hline & 800 & 150.29 & 145.60 & 26.60 & 26.00 \\
\hline \multicolumn{2}{|c|}{ Mean } & 122.30 & 129.02 & 23.40 & 24.42 \\
\hline \multirow[t]{4}{*}{100} & Control & 111.07 & 117.76 & 22.44 & 23.00 \\
\hline & 400 & 123.94 & 129.57 & 23.43 & 24.31 \\
\hline & 600 & 133.03 & 140.28 & 24.10 & 25.60 \\
\hline & 800 & 157.66 & 154.25 & 27.42 & 27.30 \\
\hline \multicolumn{2}{|c|}{ Mean } & 131.42 & 133.28 & 24.34 & 25.05 \\
\hline \multirow{4}{*}{$\begin{array}{l}\text { Mean SWE } \\
\text { concentrati } \\
\text { ons }\end{array}$} & Control & 90.21 & 95.10 & 19.32 & 20.00 \\
\hline & 400 & 102.40 & 107.68 & 20.97 & 21.67 \\
\hline & 600 & 114.86 & 120.42 & 21.93 & 23.09 \\
\hline & 800 & 134.46 & 134.10 & 24.60 & 24.57 \\
\hline \multirow{3}{*}{$\begin{array}{l}\text { L.S.D at } \\
\mathbf{5 \%}\end{array}$} & Irrigation levels & 9.30 & 7.34 & 0.96 & 0.78 \\
\hline & $\begin{array}{c}\text { SWE } \\
\text { concentrations }\end{array}$ & 10.95 & 9.00 & 1.11 & 0.90 \\
\hline & Irrigation X SWE & 11.24 & 10.81 & 1.92 & 1.56 \\
\hline
\end{tabular}


Table (10): Effect of the different irrigation water levels, seaweed concentrations and their interaction on water saturation deficit, relative water content and water use efficiency during the two seasons of 2014 and 2015.

\begin{tabular}{|c|c|c|c|c|c|c|c|}
\hline \multirow{2}{*}{$\begin{array}{c}\text { Irrigation } \\
\text { levels } \\
(\%)\end{array}$} & \multirow{2}{*}{$\begin{array}{l}\text { Seaweed extract } \\
\text { concentrations } \\
(\text { ppm })\end{array}$} & \multicolumn{2}{|c|}{$\begin{array}{c}\text { Water saturation } \\
\text { deficit }(\%)\end{array}$} & \multicolumn{2}{|c|}{$\begin{array}{l}\text { Relative water } \\
\text { content }(\%)\end{array}$} & \multicolumn{2}{|c|}{$\begin{array}{c}\text { Water use } \\
\text { efficiency }\left(\mathrm{kg} / \mathrm{m}^{3}\right)\end{array}$} \\
\hline & & $\begin{array}{c}2014 \\
\text { season }\end{array}$ & $\begin{array}{c}2015 \\
\text { season }\end{array}$ & $\begin{array}{c}2014 \\
\text { season }\end{array}$ & $\begin{array}{c}2015 \\
\text { season }\end{array}$ & $\begin{array}{c}2014 \\
\text { season }\end{array}$ & $\begin{array}{l}2015 \\
\text { season }\end{array}$ \\
\hline \multirow[t]{4}{*}{60} & Control & 26.39 & 28.94 & 73.61 & 74.06 & 1.66 & 1.65 \\
\hline & 400 & 25.59 & 27.82 & 74.41 & 75.18 & 1.82 & 1.94 \\
\hline & 600 & 23.95 & 26.11 & 76.05 & 75.89 & 2.17 & 2.27 \\
\hline & 800 & 22.84 & 24.74 & 77.16 & 78.29 & 2.51 & 2.77 \\
\hline \multicolumn{2}{|c|}{ Mean } & 24.69 & 26.91 & 75.31 & 76.09 & 2.04 & 2.16 \\
\hline \multirow[t]{4}{*}{80} & Control & 22.40 & 24.34 & 77.60 & 78.66 & 1.92 & 2.29 \\
\hline & 400 & 21.14 & 23.64 & 78.86 & 79.36 & 2.27 & 2.62 \\
\hline & 600 & 19.85 & 22.34 & 80.15 & 80.66 & 2.57 & 2.95 \\
\hline & 800 & 19.21 & 21.28 & 80.79 & 81.64 & 3.01 & 3.09 \\
\hline \multicolumn{2}{|r|}{ Mean } & 20.65 & 22.92 & 79.35 & 80.08 & 2.45 & 2.73 \\
\hline \multirow[t]{4}{*}{100} & Control & 18.58 & 17.28 & 79.74 & 81.72 & 1.76 & 1.96 \\
\hline & 400 & 16.88 & 15.04 & 80.72 & 82.96 & 1.97 & 2.15 \\
\hline & 600 & 14.60 & 13.36 & 82.42 & 83.64 & 2.11 & 2.33 \\
\hline & 800 & 12.22 & 11.56 & 84.12 & 86.44 & 2.50 & 2.57 \\
\hline \multicolumn{2}{|r|}{ Mean } & 15.57 & 14.31 & 81.75 & 83.69 & 2.08 & 2.25 \\
\hline \multirow{4}{*}{$\begin{array}{c}\text { Mean } \\
\text { SWE } \\
\text { concentrat } \\
\text { ions } \\
\end{array}$} & Control & 22.25 & 23.52 & 76.98 & 78.15 & 1.78 & 1.96 \\
\hline & 400 & 21.20 & 22.16 & 77.99 & 79.17 & 2.02 & 2.23 \\
\hline & 600 & 19.46 & 20.60 & 79.54 & 80.40 & 2.46 & 2.51 \\
\hline & 800 & 18.09 & 19.19 & 80.69 & 82.11 & 2.67 & 1.95 \\
\hline \multirow{3}{*}{$\begin{array}{l}\text { L.S.D at } \\
5 \%\end{array}$} & Irrigation levels & 0.94 & 0.67 & 0.75 & 1.00 & 0.06 & 0.04 \\
\hline & $\begin{array}{c}\text { SWE } \\
\text { concentrations }\end{array}$ & 1.09 & 0.78 & 0.82 & 1.21 & 0.09 & 0.07 \\
\hline & $\begin{array}{c}\text { Irrigation X } \\
\text { SWE }\end{array}$ & 1.89 & 1.55 & 1.01 & 1.62 & 0.12 & 0.10 \\
\hline
\end{tabular}

\section{DISCUSSION}

Before the discussion of the obtained results of this experiment, it is worthy to say that the prime consideration of this paper is to evaluate the effect of different irrigation water levels, the foliar spray with seaweed extract concentrations and their interaction on green bean plants to determine the most proper irrigation water level and the suitable seaweed concentration that gives the maximum pod yield with good quality. To discuss the changes in the tested characteristics of green bean plant, it is clear that the physical parameters of plant and pod such as plant height and the number of leaves and pod weight and length increased with the increase of irrigation levels up to $100 \%$ at Etc. In addition, the highest total yield in weight and in the number resulted from the plants exposed to the levels of $80 \%$ and $100 \%$ from Etc. These results may suggest that increasing applied irrigation water up to the optimum irrigation water level to green bean plants led to maintenance of moisture content in the root zone at low tension and this ensured adequate soil water, air and nutrients throughout the plant growth periods. Hence, the availability of moisture in the soil created good conditions for increasing the mobility of nutrients in the soil and consequently increased the minerals uptake by plant and increasing carbohydrates assimilation which led to the increase in the vegetative growth (Ezzo et al., 2010) and pod parameters (El-Nemr, 2006).The other view indicated that these results may be attributed mainly to the effect of water efficiency on the quantitative and qualitative changes in certain metabolic processes in the plant cell which led to the enhancement of cell division and enlargement and this in turn might affect all morphological parameters of the growing plants 
and much for increasing in the pod characteristics and quality (Mahmoud, 2000).

Concerning the changes occurred in the chemical characteristics, it is obvious that the leaf and pod total chlorophyll content was increased as the amount of water increased from $80 \%$ to $100 \%$ of Etc .These results may be related to the use of the suitable irrigation water level which inhibit chlorophyll enzymes activity (Abd El-Dayem et $a l$. , 2015). The present study showed that leaf proline content in the plants subjected to the irrigation water level of $60 \%$ was significantly higher than the irrigation treatments of $80 \%$ and $100 \%$. Such increase in proline content with drought conditions is one of the defense mechanisms to prevent water loss to maintain cell turgor and the gradient for water up take into cell . These accumulations in cells lead to an increase in the osmotic potential and finally resulted in higher water uptake capacity roots and water saving in the cell (Farooq et al., 2009).

Regarding the increase in ascorbic acid content as a result of using the low level of irrigation of $60 \%$ comparing with the levels of $80 \%$ and $100 \%$, this result may be attributed to the fact that the increase in ascorbic acid under the shortage of water is one of the important antioxidants for protecting the plant from the detrimental effects of drought (Smirnoff, 2005). From the obtained results, the increase in the pod protein, $\mathrm{P}$ and $\mathrm{K}$ contents with increasing the irrigation levels up to $100 \%$ of Etc may be attributed to the main role of water in increasing the absorption of macro and micro nutrients from the soil, the agent of translocation of food materials to plant parts and the main constituents in photosynthetic process which consequently affect the amounts of protein synthesis required for cells and tissues formation (Abd El-Dayem et al., 2015).

Concerning the water relations, the obtained result of water saturation deficit exerted from the irrigation $60 \%$ level of Etc was higher than from the level of $100 \%$. On the other side, the character of relative water content was increased with the increase in the irrigation levels till $100 \%$ while these values were decreased by using the level of $60 \%$. explain these results, it is well known that water saturation deficit and relative water content are important markers to measure plant water status. Hence, the adequate supply of water may increase water availability in the root zone resulting in improving plant water status which led to the enhancement of relative water content and the reduced of water saturation deficit in the plant cells (Farooq et al. 2009). With respect of the water use efficiency, our results showed that the highest value of water use efficiency was recorded from the irrigation $80 \%$ level of Etc and this may induce better utilization of soil water reserves through the promotion of root growth (Refaie, 2009).

The plants irrigated with the different irrigation water levels and sprayed with the different concentrations of seaweed extract appeared that using the irrigation level of $100 \%$ and the seaweed concentration of $800 \mathrm{ppm}$ had the highest values in the physical characteristics of the plant and pod such as plant height and number of leaves and pods number, weight and length. To discuss this trend in the previous results, it can be that spraying with the different concentrations of seaweed extract promoted plant growth and increased stress tolerance. Hence, these results may be due to containing seaweed extract to some components such as macro- and micro element nutrients, amino acids, vitamins, cytokinins and auxins like growth substances in which affect cellular metabolism in treated plants leading to enhance growth and crop yield (Zewail, 2014).

Concerning the changes in the chemical contents of the plant and pod of green bean, the results indicated that the leaf and pod total chlorophyll content increased with the increase in the irrigation levels up to $100 \%$ and the foliar spray of seaweed extract up to the concentration of $800 \mathrm{ppm}$. This increase in the content of chlorophyll may be due to the benefit effect of seaweed extract in protecting chlorophyll degradation which might be caused by betaine and betaine-like compounds present in seaweed. In plants, betaines serve as a compatible solute that alleviates osmotic stress induced by drought stress (Khan et al., 2009). Nevertheless, this increase in the photosynthetic pigments may be due to the presence of magnesium in seaweed extract which is the chief constituent for chlorophyll synthesis or due to increase in the number and size of the chloroplast and better grana development (Ramya et al., 2010). Our results refer that the increase in proline content of leaf came from the irrigation $60 \%$ level and the treating plant with seaweed extract of $800 \mathrm{ppm}$. Therefore, the accumulation of 
proline is an indicator of drought and it is one of the mechanisms of adaptation to water stress in plants (Peleg et al., 2011).

At the same time, the best results in the content of ascorbic acid in pod were achieved from using the irrigation $60 \%$ level of Etc in the plants sprayed with the concentration of $800 \mathrm{ppm}$ seaweed extract. This result confirmed the important function of seaweed extract in the tolerance to water deficit because the application of seaweed extract led to increase the activity antioxidant enzymes in plant cells which scavenges reactive oxygen species. Therefore, many researchers have reported that seaweed extracts enhance the ascorbate peroxidase activities (Ayad, 1998); demonstrating the strong antioxidant properties of seaweeds which have been correlated to bioactive compounds (Meenakshi et al. 2009). Also, it was found that seaweed extract stimulate the biosynthesis of ascorbic acid in the chloroplast which protect photosynthetic apparatus (Zhang and Schmidt, 2000). The increase in protein, N, P and K contents in pods as a result of the irrigation with the of level $100 \%$ and the concentration of seaweed extract of $800 \mathrm{ppm}$ could be attributed to the role of seaweed extract in enhancing many physiological process such as increase building metabolites, enhance cell division, chlorophyll accumulation and stimulate dry matter production as a result of higher photosynthetic activity and consequently increased translocation and accumulation of macro and micro elements in plant organs (Chhun et al., 2004) and enhanced of synthetic protein (Latique et al.,2013)

In this respect, the increases of total yield in weight and number came from using the irrigation levels at $80 \%$ and $100 \%$ of Etc and the concentration of $800 \mathrm{ppm}$ seaweed extract could be conducted with the beneficial effect of seaweed on increasing vegetative growth characteristics (Table 4), number of bods as well as weight of bods (Table, 6 and 9) and the chlorophyll formation, as well (Table 5). Therefore, under these circumstances the translocation of different photosynthetic to pods is being maximized thereby, increase the pods parameters and yield would be expected.

Regarding the water relations, the result of water saturation deficit showed that water saturation deficit was reduced from irrigation with the level at $100 \%$ of Etc and foliar spray with seaweed extract at $800 \mathrm{ppm}$. On the other hand, the plants irrigated with the irrigation $100 \%$ level of Etc and sprayed with the concentration of 800 ppm seaweed extract led to the highest value in the relative water content. It is well known that water saturation deficit and relative water content are important parameters to measure plant water status. Hence, the beneficial effect of seaweed extract in decreasing water saturation deficit and increasing relative water content may be due to exogenous application of seaweed extract has already been shown to promote root growth (Khan et al., 2009) and improve water uptake form soil thereby enhance leaf water status (Demir et al., 1999). Also, our results showed that the highest value of water use efficiency was exerted from the irrigation $80 \%$ level of Etc and foliar spray with seaweed extract at $800 \mathrm{ppm}$ and this may due to the role of seaweed extract in enhancing plant growth and increasing yield (Khan et al., 2009).

In conclusion, this study indicated that seaweed extracts applied to green bean plants under the different of irrigation water levels improved vegetative growth and reduced the water deficit effect. Hence, the beneficial effect of seaweed extract plausible that the seaweed components exhibit synergistic activity in physiological responses and stress alleviation.

\section{REFERENCES}

Abd El-Dayem H. M. M., Mady M. A. M., Abd El-All M. M. and Eid R. S. M. (2015). Effect of some antioxidants, potassium and arbuscular mycorrhiza on growth, yield and quality of snap bean plants grown under water stress levels. Ann., Agric. Sci., Moshtohor, 53: 15-30.

Allen R.G., Pereira L.S., Raes D. and Smith M. (1998). Crop evapotranspiration-guidelines for computing crop water requirements FAO Irrigation and Drainage Paper 56. FAO, Roma, Italy.

Association of Official Methods of Analytical Chemists (2005). Official Methods of Analysis $15^{\text {th }}$ ed., Published by A.O.A.C Washington, D.C., U.S.A.

Ayad J. Y. (1998). The effect of seaweed (Ascophyllum nodosum) extract on antioxidant activities and drought tolerance of tall fescue (Festuca arundinacea Schreb.). Dissertation, 
Texas Tech. Univ., UAS.

Bates S., Waldren R. and Teare I.D. (1973). Rapid determination of free proline for waterstress studies. Plant and Soil., 39:205-207.

Catasky J. (1963). Water saturation deficit and development in young and old leaves .In water relation of plants. British Ecol. Soc. Sump 3:110-112.

Chhun T., Takcta S., Tsurumi S. and Masahiko I. (2004). Different behaviour of indole-3-acetic acid and indole-3-butyric acid in stimulating lateral root development in rice (Oryza sativa L.). Plant Growth Regul., 43:135-143.

Demir D., Günes A., Inal A. and Alpaslan M. (1999). Effects of humic acids on the yield and mineral nutrition of cucumber (Cucumis sativus 1.) grown with different salinity levels. Acta Hort., 492:95-104

El-Nemr A. M. (2006). Effect of mulch types on soil environmental conditions and their effect on the growth and yield of cucumber plants. J. Applied Sci. Res., (2) : 67-73.

Ezzo M.I. Glala A.A., Habib H.A.M, and Helaly A.A. (2010). Response of sweet pepper grown in sandy and clay soil lysimeters to water regimes. American-Eurasian J. Agric. Environ. Sci., (8) : 18-26.

Farooq M., Wahid A., Kobayashi N., Fujita D. and Basra S.M.A. (2009). Plant drought tress: effects, mechanisms and management. Agron. Sustain. Dev., 29): 185-212.

Food and Agricultural Organization of united nations (FAO), Economic and social development department: The statistical division, (2013). http://faostat.fao.orgl.

Hamed E. S. (2012). Effect of seaweed extract and compost treatments on growth,yield and quality of snap bean. Ph.D. Thesis, Fac.Agric., Ain Shams Univ, Cairo, Egypt.

Hassan A.A. (1989). Fruit Vegetables. Al-Dar Al Arabia Lil Nashr Wa Al-Tawzeia (pub.), Cairo, Egypt, (In Arabic).

Hernández-Herrera R. M., Santacruz-Ruvalcaba F., Ruiz-López M.A., Norrie J. and Hernández-Carmona G. (2014). Effect of liquid seaweed extracts on growth of tomato seedlings (Solanum lycopersicum L.). J. Appl. Phycol., 26:619-628.

Ibrahim S.A.A. (2012). Effect of some antioxidant substances on physiological and anatomical characters of wheat plant grown under drought conditions. Ph.D., Thesis. Fac. Agric. Zagazig Univ. Egypt.

Khan W., Rayirath U.P., Subramanian S., Jithesh M.N., Rayorath P., Hodges D.M., Critchley A.T., Craigie J.S., Norrie J. and Prithivira B. (2009). Seaweed extracts as bio stimulants of plant growth and development. J. Plant Growth Regul., 28: 386-399.

Korkmaz A., Korkmaz Y. and Demirkiran A.R. (2010). Enhancing chilling stress tolerance of pepper seedling by exogenous application of 5-aminolevolinic acid. Environ. Exper. Bot., 67: 495-501.

Latique S., Chernane H., Mansori M. and El Kaoua M. (2013). Seaweed liquid fertilizer effect on physiological and biochemical parameters of bean plant (Phaseolus vulgaris L. variety Paulista) under hydroponic system. Europ. Sci. J., 9: 174-191.

Lichtenthaler H. K. (1987). Chlorophylls and Carotenoids: Pigments of Photosynthetic Biomembranes. Method. Enzymol., 148: 350-382.

Mahmoud H.A. (2000). Effect of irrigation on growth and yield of pea (Pisum sativum L.) M.Sc., Thesis. Fac. Agric. Minufia Univ. Egypt.

Mansori M., Chernane H., Latique S., Benaliat A., Hsissou D. and El Kaoua M. (2016). Effect of seaweed extract (Ulva rigida) on the water deficit tolerance of Salvia officinalis L. J. Appl Phycol ., 28:1363-1370.

Meenakshi S., Manicka D. G., Tamil S., Arumugam M. and Balasubramanian T. (2009). Total flavonoid and in vitro antioxidant activity of two seaweeds of Rameshwaram Coast. Global J. Pharmacol., 3: 59-62.

Peleg Z., Apse M.P. and Blumwald E. (2011). Engineering salinity and water-stress tolerance in crop plants: getting closer to the field. Adv. Bot. Res., 57:405-443.

Ramya S. S., Nagaraj S. and Vijayanand N. (2010). Biofertilizing efficiency of brown and green algae on growth, biochemichal and yield parameters of Cyamopsis tetragonolaba (L.) Taub. Recent Res. Sci. Tech., 2:45-52.

Refaei K.M. (2009). Water balance of potato crop under North Delta conditions. Ph. D. Thesis, Fac. Agric., Al-Azhar Univ., Egypt.

Snedecor G. W. and Cochran W. G. (1980). 
Statistical Methods ( $8^{\text {th }}$ Ed.), Iowa State. Univ. Press. USA.

Singer S. M., Helmy Y. I., Karas A. N. and AbouHadid A. F. (2003). Influences of different water-stress treatments on growth, development and production of snap bean (Phaseolus vulgaris L.). Acta Hort., 614:605611.

Smirnoff N. (2005). Ascorbate, tocopherol and carotenoids: metabolism, pathway engineering and functions. In: Smirnoff N, (ed). Antioxidants and reactive oxygen species in plants. Oxford: Blackwell Publishing,U.K. pp. 53-86.

Srinivas K., Hegde D.M. and Havanagi G.V. (1989). Plant water relation, canopy temperature, yield and water use efficiency of watermelon Citrullus lanatus (Thunb) Matsum et Nakai under drip and furrow irrigation. J. Hort. Sci., 64:115-124.

Thaloot T. A., Tawfik M. M. and Mohamed H. M. (2006). A Comparative study on the effect of foliar application zinc, potassium, magnesium on growth, yield and some chemical constituents of mungbean plants grown under water stress condition. World J. Agric. Sci., 2: 37- 46.

Zewail R. M. Y. J. (2014). Effect of seaweed extract and amino acids on growth and productivity and some biocostituents of commen bean (Phaseolus vulgaris L.) plants. Plant Produc., Mansoura Univ., 5: 1441 1453.

Zhang S., Weng J., Pan J., Tu T., Yao S. and Xu C. (2003). Study on the photogeneration of superoxide radicals in Photosystem II with EPRspin trapping techniques. Photosynth. Res., 75:41-48.

Zhang X. and Schmidt R.E. (2000). Hormonecontaining products' impact on antioxidant status of tall fescue and creeping bent grass subjected to drought. Crop Sci., 40: 13441349.

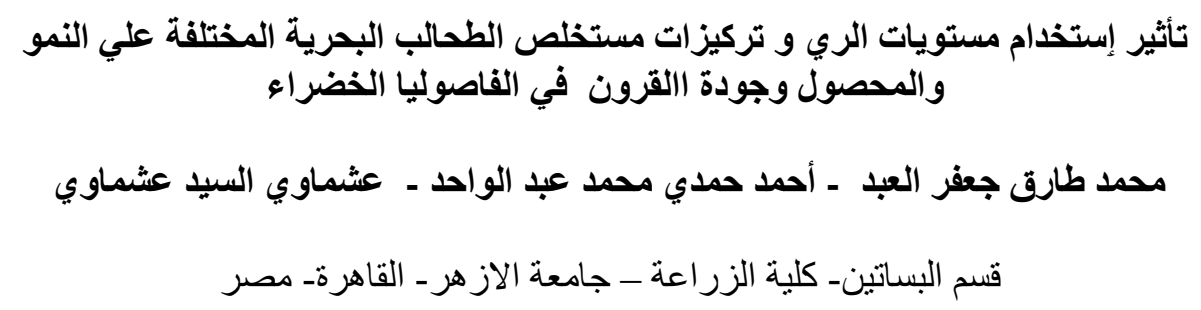

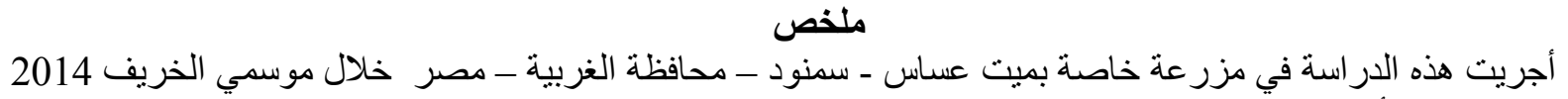

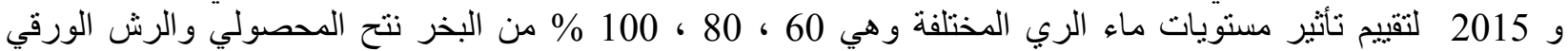

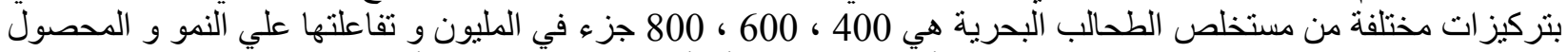

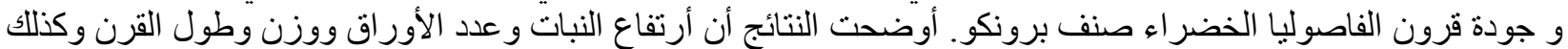

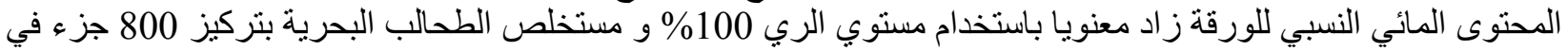

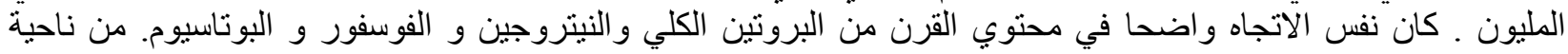

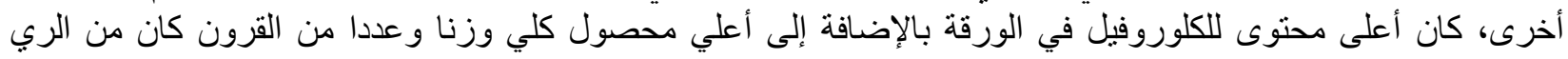

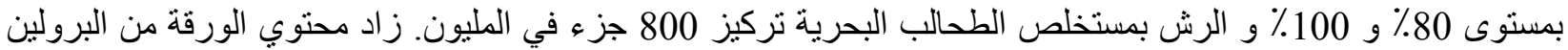

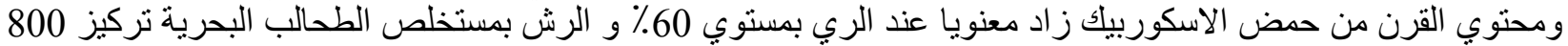

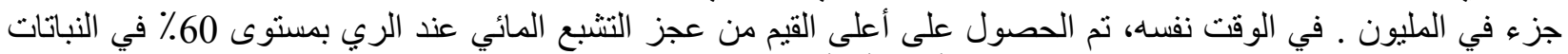

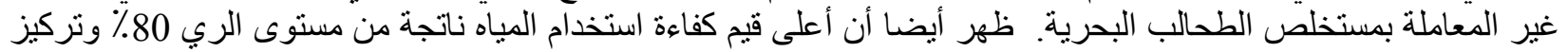

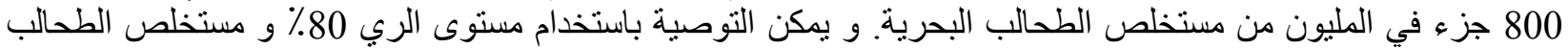
البحرية بتركيز 800 جزء في المليون كتطبيق مناسب لزيادة محصول قرون الفاصوليا الفيا الخضراء بأعلي كفاءة في استخدام المياه.

المجلة العلمية لكلية الزراعة جامعة القاهرة - المجلا (67) العدد الرابع (أكتوبر 2016 ):340-327. 